\title{
PATHOMORPHOLOGICAL PICTURE OF LUNGS OF WHITE RATS WITH PRECLINICAL STUDY OF UVMC «LIZUNETS»
}

\author{
DAMIR D. HAIRULLIN ${ }^{1}$, ELENA G. GUBEEVA ${ }^{2}$, FARIT F. ZINNATOV ${ }^{1}$, ALIYA R. KASHAEVA ${ }^{1}$, \\ ALEXANDER P. OVSYANNIKOV ${ }^{1}$, AZAMAT H. SHANTYZ ${ }^{3}$, ANDREY V. MALNEV ${ }^{2}$, DAMIR V. \\ ALEEV $^{2}$, GUZALIA R. YAMALOVA ${ }^{2}$, KADRIYA F. KHALIKOVA ${ }^{2}$, GULNARA G. GALYAUTDINOVA ${ }^{2}$ \\ ${ }^{1}$ Kazan State Academy of Veterinary Medicine named after N.E. Bauman, Russia \\ ${ }^{2}$ Federal Center for Toxicological, Radiation and Biological Safety, Kazan City, Russia \\ ${ }^{3}$ Kuban State Agrarian University named after I.T. Trubilin, Krasnodar City, Russia
}

ABSTRACT
In order to study the Toxicological properties of carbohydrate-vitamin-mineral concentrate «Lizunets», subchronic
toxicity experiments were conducted on clinically healthy mongrel white rats. Animals kept in vivarium conditions
were given distilled water inside the control group, and animals of the experimental group were given a feed
additive in the form of an aqueous suspension of UVMC «Lizunets» in different doses inside with the help of an
atraumatic probe. In experimental animals, the physiological state, behavioral responses, and use of feed and water
were studied, so that they did not differ from the control groups of white rats. The results of anatomical and
topographical and morphological studies of internal organs and lungs of white rats showed that the use of UVMC
«Lizunets» during the study was not accompanied by undesirable changes. Histological examination of the lungs of
white rats of experimental and control groups allows us to conclude that no undesirable deviations were detected.
KEYWORDS: Pathomorphology, White Rats, Feed Additives

Received: Jun 08, 2020; Accepted: Jun 28, 2020; Published: Aug 18, 2020; Paper Id.: IJMPERDJUN2020790

\section{INTRODUCTION}

In modern conditions, the key to the profitable development of animal husbandry is the cultivation of highly productive animals with different genetic levels of different breeds. At the same time, there is a question about the fullness of the animal feeding diet, which is known for incomplete and unbalanced feeding of animals, especially highly productive animals, which leads to various diseases such as metabolic disorders, that they become more prone to infectious and noninfectious diseases, which leads to the loss of the productive level of animals and makes the livestock industry economically unprofitable (Kadikov et al., 2018; Galyautdinovaet al., 2020; Hairullinet al., 2020).

Currently, for preventive purposes, a large number of feed additives are used in the form of briquettes, lizunts, premixes, which are recommended for use in the cultivation of farm animals.

But there is no exception that they can negatively affect the morpho functional state of internal organs and systems of animals (Semenov et al., 2017; Kireevet al., 2018).

Morphological studies will help to find out both the structure of the organ as a whole, and its changes occurring in certain areas and components of the studied samples. Based on certain morphological features of various tissue and cellular structures, it is possible to identify violations in the form of deviations from the standard indicators of organ tissues (Smolentsevet al., 2020; Yakupovet al., 2020; Zinnatovet al., 2020). 
In this connection, the purpose of our research was to study the possible influence of the use of UVMC «Lizunets» in different doses on the morphological characteristics of internal organs and histological changes in the lungs of white rats during preclinical research.

\section{MATERIALS AND METHODS}

Preclinical studies on the subchronic toxicity of UVMC «Lizunets» were conducted on clinically healthy mongrel white rats with a live weight of 55 to $60 \mathrm{~g}$, which were kept in a vivarium of the Kazan gavm. 4 groups of white rats of different sexes with 12 heads each were selected. The first group served as a control and received distilled water, which was given inside using an atraumatic probe. Animals of the second experimental group were given a feed additive UVMC «Lizunets» in the form of an aqueous suspension of $1 / 10$ of the conditional $\mathrm{LD}_{50}$ at a dose of $800 \mathrm{mg} / \mathrm{kg}$, - animals of the third experimental group $400 \mathrm{mg} / \mathrm{kg}$, - the fourth experimental group $160 \mathrm{mg} / \mathrm{kg}$ of live weight. The volume of the suspension did not exceed more than $2 \mathrm{ml}$ per head. At the same time, their external condition, reception of the main feed and water were noted. At the same time, they followed the methodology set out in the «Guidelines for conducting preclinical studies of medicines» (Mironov A.N., 2012).

After 30 days, the experimental animals were put to death under ether anesthesia in compliance with the rules of euthanasia. After biological death, the thoracic and abdominal cavities were opened and organs were extracted for histological examination. The pieces of organs were fixed in a neutral $10 \%$ formalin solution and sent to the laboratory for study.

\section{RESULTS AND DISCUSSIONS}

It was found that during the use of the feed additive UVMC «Lizunets» animals of the experimental group did not notice changes in behavior, external and physiological state in comparison with the animals of the control group. It was also found that anatomical and topographical studies of internal organs did not show any changes in the rats of the experimental groups (Fig.1, 2).

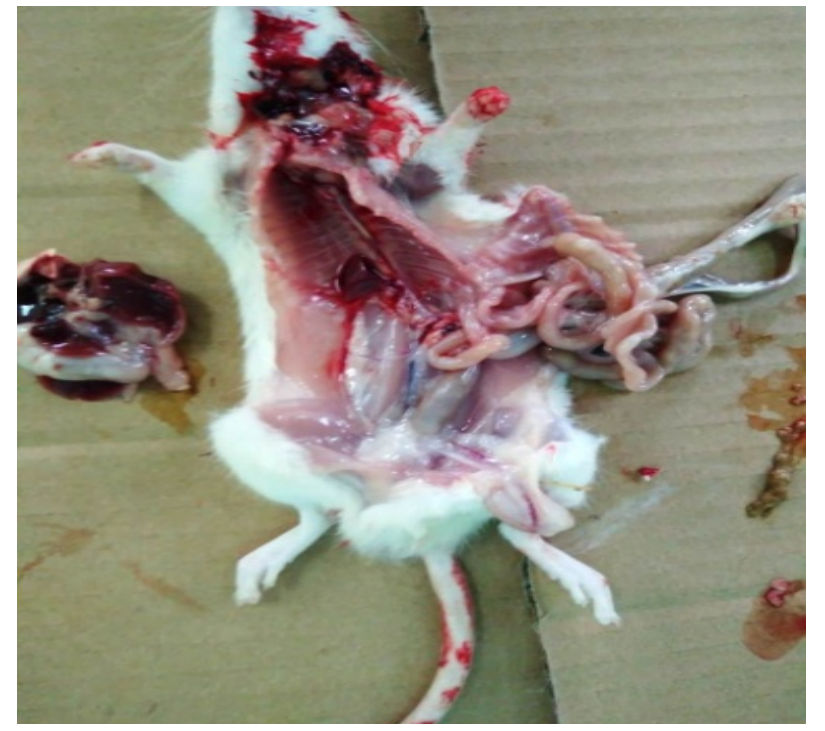

Figure 1

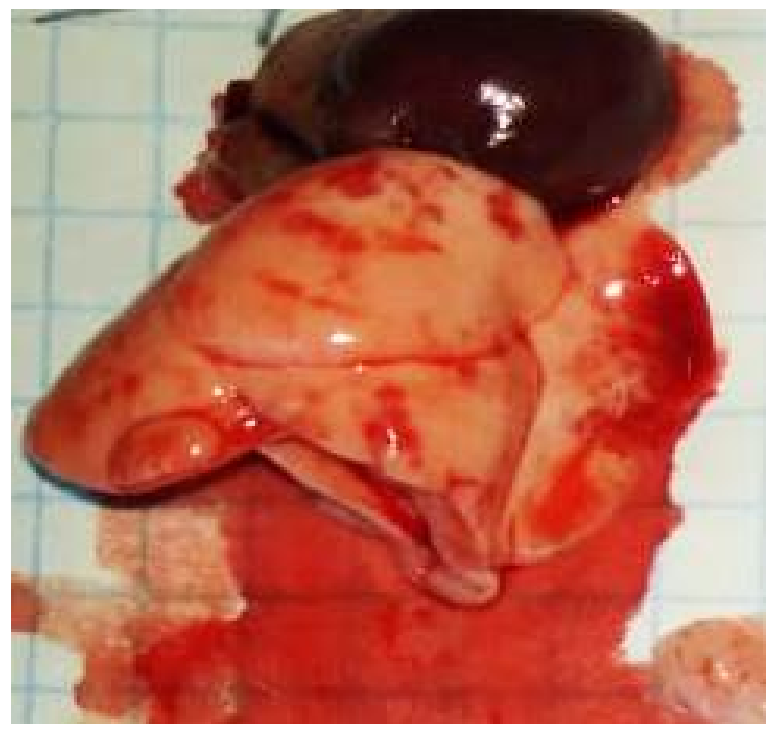

Figure 2

Figure 1 \& 2: Anatomical and Topographic Studies of Internal Organs of White Rat. 


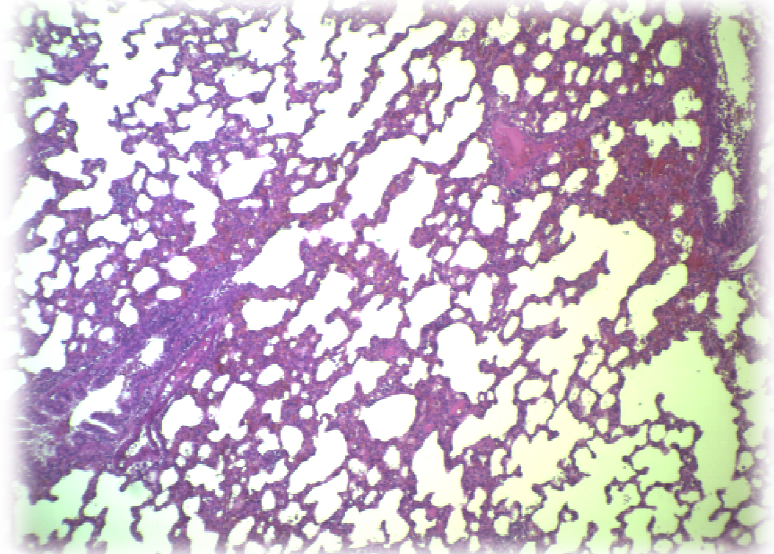

Figure 4: Lung of the First Control Group of Rats.

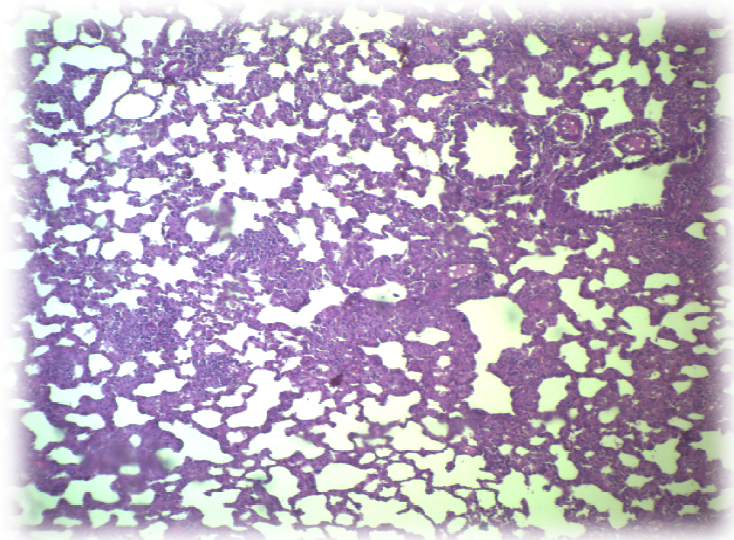

Figure 6: Lung Rats of the Third Experimental Group.

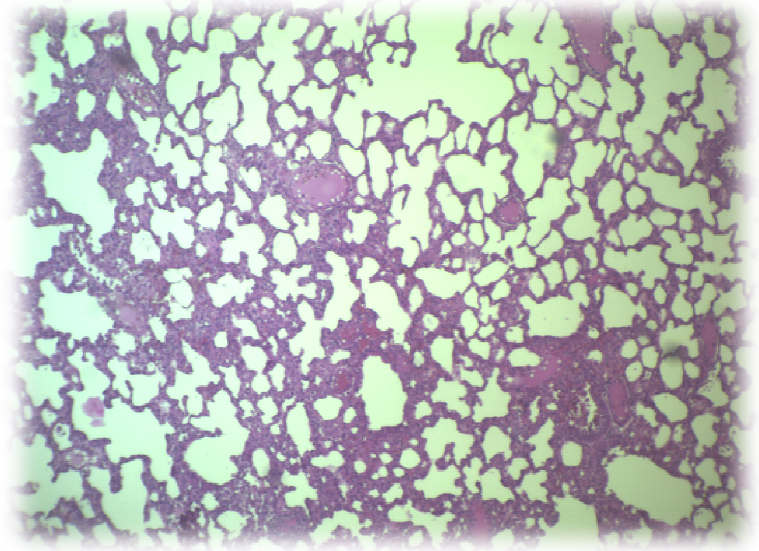

Figure 5: Lung of the Second Experimental Group of Rats.

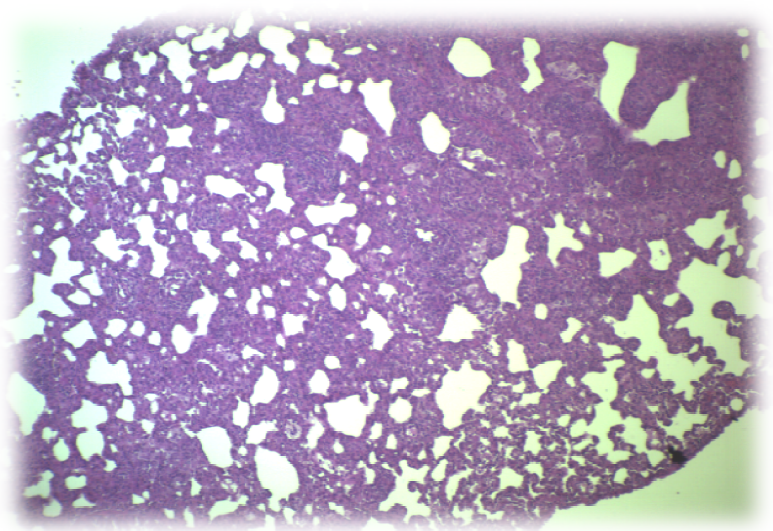

Figure 7: Lung of the Fourth Experimental Group of Rats.

Histological examination of the lung tissue of white rats in the control group (Fig.4) revealed that small bronchi in oblique sections, bronchioles and alveoli were found in the section. The walls of the bronchi are lined with a multi-row cylindrical ciliated epithelium. The folding of their walls is determined, the lumen is «corrugated», they contain a small amount of eosinophilic masses on the surface of the mucosa, single white blood cells. The alveoli are expanded, their lumen is free. Veins extended eritromicina and filled with homogeneous eosinophilic masses, isolated leucocytes.

In the lungs of the second experimental group of rats (Fig. 5), there are bronchioles lined with cylindrical ciliated epithelium in the field of view. In the section, the alveoli are expanded, some merge 3-4 pieces and form a single cavity. The alveolar lumen is free. Blood filling is uneven. Arteries are anemic or desolate. Enlarged veins, filled with erythromyci, homogeneous eosinophilic masses and isolated leukocytes.

The structure of the lung of rats of the third experimental group (Fig. 6) is similar to the control. The section contains small bronchi, in which you can see a small cartilage. The lumen of the bronchi is free and has a wavy appearance. The mucous layer is represented by a multi-row cylindrical ciliated epithelium located on the basement membrane. His colored basophilic nucleus, slightly elongated. Behind the basal membrane, a thin muscle layer is defined, followed by connective tissue. Alveoli have free lumen, expanded. Vessels in the drug are unevenly expanded, veins and capillaries are filled with Erythro -, homogeneous and eosinophilic masses. 
In the lung tissue of rats of the fourth experimental group (Fig. 7). Arteries in the preparation are anemic or empty, veins and capillaries are filled with red blood cells, homogeneous eosinophilic masses and leukocytes. Clusters of white blood cells are detected around the vessels. The walls of small and medium bronchi are thickened and infiltrated by leukocytes. The multi-row cylindrical ciliated epithelium is swollen. In the lumen of the bronchi, homogeneous eosinophilic masses, white blood cells. In the connective tissue surrounding the bronchi, eosinophilic masses and white blood cells are determined. The alveoli in the drug are unevenly expanded, some have dormant lumen. Approximately in the $1 / 4$ part of the alveoli, homogeneous eosinophilic masses and white blood cells are determined. In some alveoli, alveolar cells are found among the eosinophilic masses.

\section{CONCLUSIONS}

Thus, the results of anatomical and topographical and morphological studies of internal organs and lungs of white rats showed that the use of UVMC «Lizunets» during the study at different doses was not accompanied by undesirable changes. Histological examination of the lung of white rats of experimental and control groups allows us to conclude that undesirable deviations were also not detected.

\section{REFERENCES}

1. Galyautdinova, G.G., Egorov, V.I., Saifutdinov, A.M., Rakhmetova, E.R., Malanev, A.V., Aleyev, D.V., Smolentsev, S.Yu., Semenov, E.I. 2020. Detection of tetracycline antibiotics in honey using high-performance liquid chromatography. International Journal of Research in Pharmaceutical Sciences, 11(1): 311-314.

2. Hairullin, D.D., Zinnatov, F.F., Shakirov, Sh.K., Papaev, R.M., Nurgaliev, F.M., Kamaldinov, I.N.,Ovsyannikov, A.P. 2020. Study of scar content in cows when using carbohydrate-vitamin-mineral concentrate

3. «LS». International journal of research pharmaceutical sciences, 11(2): 2241-2243.

4. Kadikov, I.R. Papunidi, K.K., Korchemkin, A.A., Vafin, I.F., Semenov, E.I., Idiatov, I.I., Zakirova, G.S. 2018. Comparative evaluation of agents for preventive therapy for combined intoxications with xenobiotics in poultry. Indian Veterinary Journal, 95(7): 29-32.

5. Kireev, I.V.,Orobets V.A., Denisenko, T.S., Shantyz, A.Kh. 2018. The effectiveness of the joint use of antioxidant and antistress agents in the experimental modeling of technological stress for rabbits.Research Journal of Pharmaceutical, Biological and Chemical Sciences, 9(4): 1059-1066.

6. Semenov, E.I.,Mishina, N.N., Kadikov, I.R., Smolentsev, S.Yu., Nikitin, A.I., Papunidi, K.K. Tremasov, M.Y. 2017. Screening drugs-potential immunomodulators for t-2 mycotoxicosis.Bali Medical Journal, 6(2): 110-114.

7. Smolentsev, S.Yu.,Matrosova, L.E., Chekhodaridi, F.N., Gadzaonov, R.Kh., Kozyrev, S.G., Gugkaeva, M.S., Kornaeva, A.K. 2020. Effectiveness of probiotics use in poultry farming. International Journal of Pharmaceutical Sciences and Research, 11(1): 179-182.

8. Yakupov, T.R., Valiev, M.M., Zinnatov, F.F., Alimov, A.M., Galiullin, A.K., Hairullin, D.D., Papaev, R.M., Smolentsev, S.Yu. 2020. Features of humoral immunity in cows infectedwith the leukaemia virus.International journal of research in pharmaceutical sciences, 11(1): 290-293.

9. Zinnatov, F.F.,Zinnatova, F.F., Volkov, A.H., Akhmetov, T.M., Alimov, A.M., Yakupov, T.R., Hairullin, D.D., Safina, N.Yu. 2020. Studying the association of polymorphic variants of lep, $\operatorname{tg} 5, \mathrm{csn} 3$, lgb genes with signs of dairy productivity of cattle. International Journal of Research in Pharmaceutical Sciences, 11(2): 1428-1432. 